\title{
Influence of different pectinolytic enzymes on bioactive compound content, antioxidant potency, colour and turbidity of chokeberry juice
}

\author{
Sabina Lachowicz ${ }^{1}$ · Jan Oszmiański ${ }^{1}$ · Joanna Kolniak-Ostek ${ }^{1}$
}

Received: 15 April 2018 / Revised: 26 May 2018 / Accepted: 27 May 2018 / Published online: 7 June 2018

(c) The Author(s) 2018

\begin{abstract}
The aim of this study was to investigate the influence of addition of pectinolytic enzymes to chokeberry juice on the content of polyphenolic compounds analysed by UPLC-PDA-FL, antioxidant potency measured by ABTS and FRAP assay, turbidity, precipitation, and sugar composition analysed by HPLC-ELSD and colour parameters determined by the CIEL*a*b* system. UPLC-PDA-FL analysis identified 30 polyphenolic compounds belonging to hydroxycinnamic acids, anthocyanins, flavonones, flavonols, and flavan-3-ols. High content of bioactive compounds, high antioxidant capacity and low values of turbidity and precipitation were obtained in juice with addition of Panzym YELD MASH, Pectinex YELD MASH and Opti EYXL. The colour of chokeberry juice with these enzymes was intensely red, attractive, and without browning before or after storage. These pectinolytic enzymes influenced the stability of parameters such as chemical, physical and bioactive potency in the chokeberry juice after 5 months of storage at $5{ }^{\circ} \mathrm{C}$.
\end{abstract}

Keywords Chokeberry juice $\cdot$ Pectinolytic enzymes $\cdot$ Polyphenols $\cdot$ Antioxidant capacity $\cdot$ Turbidity $\cdot$ UPLC-PDA-MS/MS

\section{Introduction}

The systematically growing consumers' awareness of the quality of food, and especially the content of secondary plant metabolites in it, positively affects the right choice of healthy food products. Fruit juices have recently been perceived as functional foods as they have high contents of bioactive compounds [1-4]. Especially red fruit juices, mainly from chokeberry, are gaining in popularity due to their high content of biologically active substances, specifically polyphenolic compounds, and because of their taste and appealing colour. This colour is created by anthocyanins, which are polyphenols. Moreover, it has been proven that anthocyanins possess beneficial health effects on the human body [5-7]. Therefore, the content of polyphenolic compounds in juices is a matter of sensory quality as well as having potential biological effects.

Sabina Lachowicz

sabina.lachowicz@upwr.edu.pl

1 Department of Fruit, Vegetable and Plant Nutraceutical Technology, Faculty of Biotechnology and Food Science, Wrocław University of Environmental and Life Sciences, 37 Chełmońskiego Street, 51-630 Wrocław, Poland
Unfortunately, many technological processes contribute to large losses of secondary plant metabolites, which in turn lead to a decrease in the nutritional quality and functionality of final products. Currently, the juice market is constantly improving the applied technological measures towards greater preservation of valuable food ingredients $[5,7]$.

Most of the bioactive compounds are located in the chokeberry fruit skin. Therefore, the production of berry juices necessitates the disintegration of raw material to release the liquid. For this purpose, most often maceration enzymes are used, to increase extraction yield and decrease viscosity. Pectinolytic enzymes cause degradation of cell walls, resulting in easier extraction of the compounds contained in cells [8]. Furthermore, enzymatic treatment enhances the extractability of polyphenolics from the cell wall. Pectinases have been proposed to improve clarification of juice and decrease viscosity to improve the filtration process $[9,10]$. The used enzymes may also affect the chemistry of the extracted polyphenolic glycosides. Wightman and Wrolstad [11] explored differences of commercial pectinase preparations to evaluate their effect on cranberry juice anthocyanin hydrolysis. They demonstrated that arabinoside pigments were not degraded but galactosides were degraded by $2-100 \%$, depending on the used enzyme. Unfortunately, 
there is no information in the literature about pectinolytic enzymes that can be used for chokeberry juice.

Therefore, the aim of this study was to evaluate the influence of addition of pectinolytic enzymes to chokeberry juice on the content of polyphenolic compounds analysed by UPLC-PDA-FL, antioxidant potency analysed by ABTS and FRAP assays, turbidity, precipitation, and sugar composition analysed by HPLC-ELSD and colour determined in the CIEL*a*b* system. An additional aim was to investigate the influence of storage for 5 months at $5{ }^{\circ} \mathrm{C}$ on the stability of chemical, physical and bioactive parameters of chokeberry juice.

\section{Materials and Methods}

\section{Chemicals}

2,2'-Azinobis(3-ethylbenzothiazoline-6-sulfonic acid) (ABTS), 6-hydroxy-2,5,7,8-tetramethylchroman-2-carboxylic acid (Trolox), 2,4,6-tri(2-pyridyl)-s-triazine (TPTZ), methanol acetic acid and phloroglucinol were purchased from Sigma-Aldrich (Steinheim, Germany). (-)-Epicatechin, (+)-catechin, procyanidin B2, chlorogenic acid, neochlorogenic acid, cryptochlorogenic acid, caffeic acid, dicaffeoylquinic acid, $p$-coumaric acid, isoquercetin, cyanidin-3-O-galactoside and cyanidin-3-O-glucoside were purchased from Extrasynthese (Lyon, France). Acetonitrile for ultraphase liquid chromatography (UPLC; gradient grade) and ascorbic acid were from Merck (Darmstadt, Germany). Enzyms: Panzym YELD MASH, Pectinex: Ultra Color, XXL, ULTRA SPL, YELD MASH, AFP L-4, BE XXL, SMASH XXL, Opti EYXL were from Eaton (Poland).

\section{Samples}

\section{Chokeberry juices}

The experimental material consisted of chokeberry juice $(\sim 10 \mathrm{~L})$ of the Galicjanka cultivar. Juices were obtained from the company Tymbark-MWS Sp. zo.o., in Tymbark, near Kraków, Poland (49 $\left.43^{\prime} 45^{\prime \prime} \mathrm{N} 20^{\circ} 19^{\prime} 27^{\prime \prime} \mathrm{E}\right)$, in 2017 from production in September.

\section{Preparation of chokeberry juice}

To the all samples of chokeberry juices (in volume $1 \mathrm{~L}$ each) $1 \mathrm{~mL}$ of pectinolytic enzymes such as Panzym YELD MASH, Pectinex Color, Pectinex XXL, Pectinex ULTRA SPL, Pectinex YELD MASH, Pectinex AFP L-4, Opti EYXL, Pectinex BE XXL, Pectinex SMASH XXL was added. The juice (control sample) and juices with enzymes were conducted at $25{ }^{\circ} \mathrm{C}$ in centrifuge vessels in volume $0.5 \mathrm{~L}$ each for $24 \mathrm{~h}$.

After $24 \mathrm{~h}$ incubation, the samples were centrifuged $\left(19,000 \times g\right.$ for $15 \mathrm{~min}$ at $\left.20^{\circ} \mathrm{C}\right)$ and analysed. Additionally, the samples of chokeberry juice were stored for 5 months at $5{ }^{\circ} \mathrm{C}$ with addition of $0.2 \mathrm{~g} / \mathrm{L}$ dimethyl dicarbonate (Velcorin) (Lanxess Energizing Chemistry Germany). The aim of storage was to investigate the stability or change physical-chemical parameters of the juices.

\section{Precipitate values, viscosities and turbidity measurement}

Samples of chokeberry juice were weighed to $50-\mathrm{mL}$ centrifuge vessels. After centrifugation at $19,000 \times g$ for $15 \mathrm{~min}$ at $20^{\circ} \mathrm{C}$, liquid was separated. The centrifuge vessels were transferred again with the precipitate on the analytical laboratory scale to the nearest $0.0001 \mathrm{~g}$ and then after $24 \mathrm{~h}$ the amount of precipitate was weighed without juice and calculated [12].

The viscosities of the chokeberry juices without precipitate were measured with a rotation viscometer MC1 (DV-II + PRO VISCOMETER, Brookfield, England), with spindle ' 61 '. The spindle was rotated at $100 \times g$ for $30 \mathrm{~s}$ at $20{ }^{\circ} \mathrm{C}$ [12]. All measurements were repeated three times. The results were expressed as mPas.

The turbidity of juices without precipitate were measured with a turbidimeter Turbiquant 3000T (Merck, Germany) using $2.5-\mathrm{cm}$ round cuvettes. All measurements were repeated three times. Turbidity was expressed in nephelometric turbidity units (NTU) at $20{ }^{\circ} \mathrm{C}$, respectively [12].

\section{Qualitative and quantitative assessment of polyphenols}

Qualitative (LC/MS QTOF) and quantitative (UPLC-PDAFL) analysis of polyphenols (anthocyanins, flavan-3-ols, flavonols, and phenolic acids) was performed as described previously by Lachowicz, Oszmiański and Pluta [13]. All measurements were repeated three times. The results were expressed as $\mathrm{mg} / 100 \mathrm{~mL}$.

\section{Analysis of proanthocyanidins by phloroglucinolysis}

Direct phloroglucinolysis of freeze-dried samples was performed as described by Lachowicz et al. [14] on reversephase HPLC (RP-HPLC) analysis and phloroglucinol products were separated on a Cadenza CD C18 (75-4.6 mm, $3 \mu \mathrm{m})$ column (Imtakt, Japan). All data were obtained in triplicates. The results were expressed as $\mathrm{mg} / 100 \mathrm{~mL}$. 


\section{Determination of antioxidant activity}

The solvent for analysis was prepared and described previously by Lachowicz et al. [14]. The ABTS and FRAP assays were conducted as previously described by Re et al. [15] and Benzie and Strain [16], respectively. Measurements by ABTS and FRAP were performed using a UV-2401 PC spectrophotometer (Shimadzu, Kyoto, Japan). The antioxidant activity was expressed as mmol Trolox/100 mL.

\section{Analysis of sugar}

Quantitative (HPLC-ELSD) analysis of sugar was performed as described previously by Oszmiański and Lachowicz [17]. All measurements were repeated three times. The results were expressed as $\mathrm{g} / 100 \mathrm{~mL}$.

\section{Colour measurement}

Colour properties $\left(L^{*}, a^{*}, b^{*}\right)$ of chokeberry juices were analysed by reflectance measurement with a Colour Quest XE Hunter Lab colourimeter. The samples were determined according to the method described by Lachowicz et al. [12].

The total change in chokeberry juice was expressed $(\Delta E)$, chroma difference $(\Delta C)$ and hue angle $\left(H^{0}\right)$ according to the following equation described by Lachowicz at al [14].

\section{Statistical analysis}

Statistical analysis, one-way ANOVA, principal component analysis (PCA), medium significance and hierarchal cluster (HA) were conducted using Statistica version 13.0 (StatSoft, Kraków, Poland). Significant differences $(P \leq 0.05)$ between mean values were evaluated by one-way ANOVA and Duncan's multiple range test.

\section{Results and discussion}

\section{Impact of pectinolytic enzymes on content of polyphenols}

Identification of 30 polyphenolic compounds belonging to hydroxycinnamic acids, anthocyanins, flavonones, flavonols, and flavan-3-ols (monomeric, oligomeric and polymeric procyanidins) was based on a comparison of MS and MS/MS available standards, their retention times and published data reported in previous research [17-20]. The identification and quantitative results are shown in Tables 1 and 2 but the sum of individual groups of polyphenolic compounds is presented in Fig. 1. The results of measured polyphenolic compounds in the control sample and with enzymes before and after storage are presented in Table 1 and Fig. 1. The use of pectinolytic enzymes had a significant effect $(P<0.05)$ on the content of polyphenols. The content of polyphenolic compounds in chokeberry juice without enzymes was $1676.44 \mathrm{mg} / 100 \mathrm{~mL}$ and was $4 \%$ lower than polyphenols in juices with enzymes. The largest increase of phenolic compounds after $24 \mathrm{~h}$ was found in juice with addition of Pectinex YELD MASH (13\%), Panzym YELD MASH (11\%), BE XXL (9\%) and Ultra Color (4\%) enzymes. According to Landbo and Meyer [21], the use of the enzymatic preparations Pectinex BE and Pectinex Ultra SPL for the maceration of blackcurrant resulted in an increase in yield of polyphenolic compounds by 10 and $4 \%$. Bagger-Jørgensen and Meyer [22] demonstrated that the use of Pectinex ULTRA SP-L enzyme led to $14-15 \%$ higher polyphenol content in blackcurrant juice than those without enzymes. Buchert et al. [23] found that the use of pectinolytic enzymes-Pectinex BE, Ultra SP-L and SMASHpositively affected the value of polyphenols in blackcurrant juice. This content was about 20, 12 and $7 \%$ higher than in a control sample, respectively. After 5 months' storage at $5{ }^{\circ} \mathrm{C}$, the content of polyphenolic compounds in control juice was $7 \%$ lower than before storage. The largest protective effect of phenolic compounds was found in the chokeberry juice with addition of Pectinex XELD MASH, AFP L-4 and BE XXL, and the largest decrease was identified in juice with addition of Pectinex XXL and ULTRA SPL (Table 2; Fig. 1). Protection of these compounds in juices is very important to satisfy a demand by people for products with a high value of bioactive components.

The group accounted for $27 \%$ of all polyphenolic compounds was anthocyanins. The use of pectinolytic enzymes had a significant effect $(P<0.05)$ on the concentration of anthocyanins. The content of anthocyanins in the control sample was $522.57 \mathrm{mg} / 100 \mathrm{~mL}$. In juice with addition of Pectinex YELD MASH (18\%), Panzym YELD MASH (22\%) and Pectinex BE XXL (2\%) enzymes, the content of anthocyanins after $24 \mathrm{~h}$ were 22,18 and $2 \%$ higher than control samples. The concentration of anthocyanins in samples with Pectinex AFP L-4, XXL, and ULTRA SPL were around 36,34 and $31 \%$ lower than control samples. Additionally, cyanidin-3-O-galactoside was the dominant compound belonging to anthocyanins in juice and accounted for on average $50 \%$ of all compounds. The content of this compound in samples with Panzym YELD MASH and Pectinex YELD MASH was 18 and 22\% higher than in the control sample. The addition of Pectinex Color, XXL, ULTRA SPL, AFP L-4 and Opti EYXL to the juice led to an increase of aglycone cyanidin and at the same time reduced the content of cyanidin-3-O-galactoside. After 5 months' storage the content of anthocyanins in the control sample was $9 \%$ lower than before storage. The largest decrease of the concentration of anthocyanins was identified in juice with addition of Pectinex XXL (63\%), ULTRA SPL (69\%) and YELD 


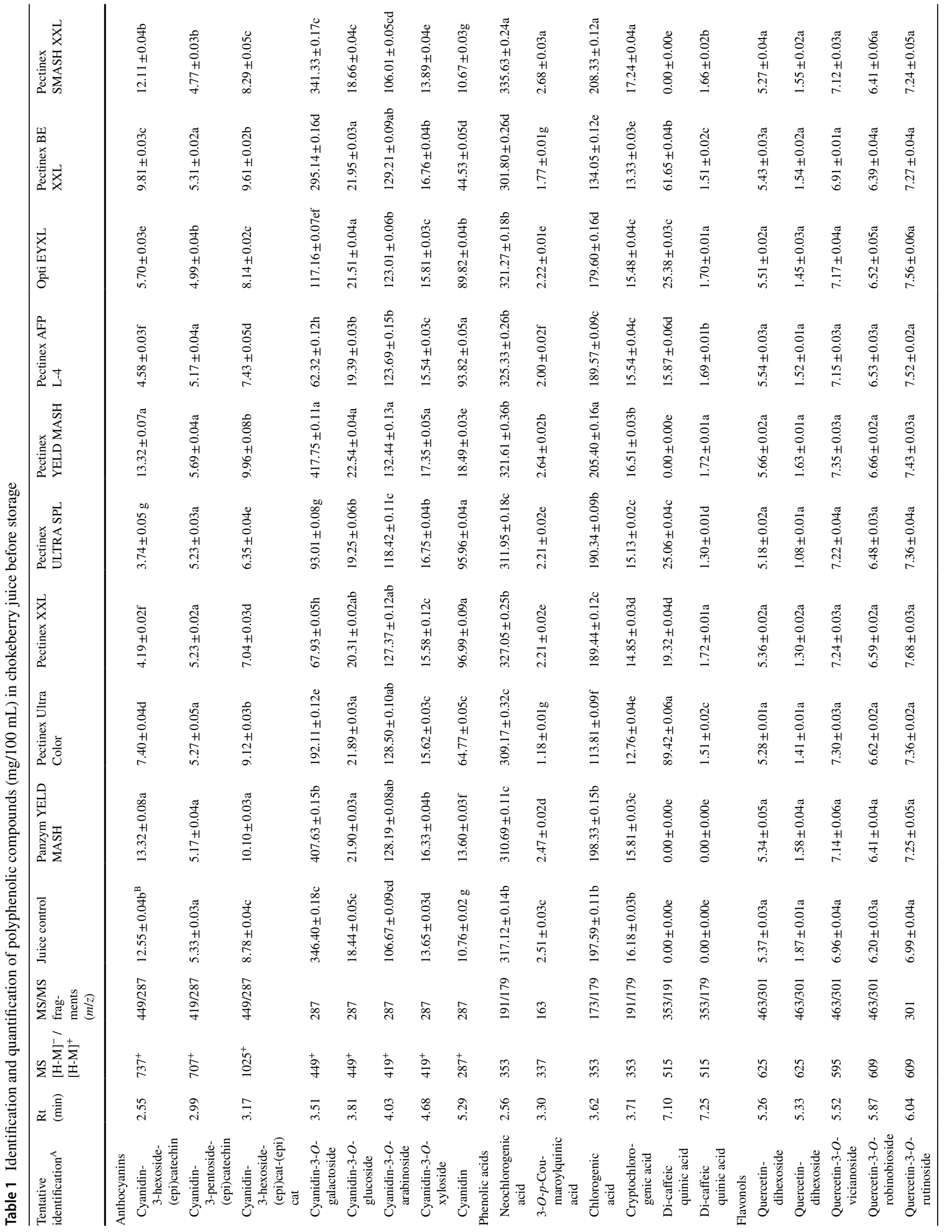




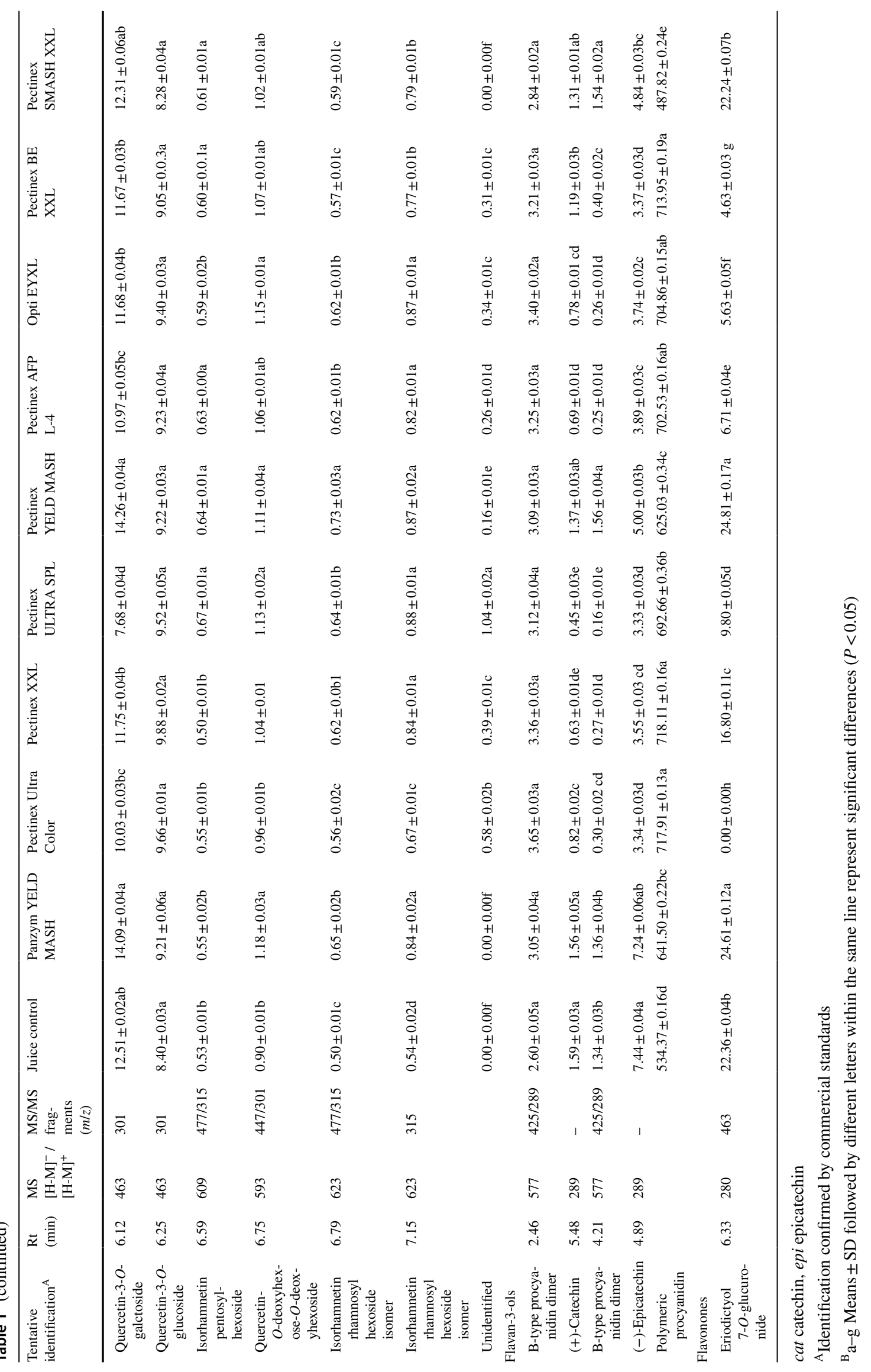




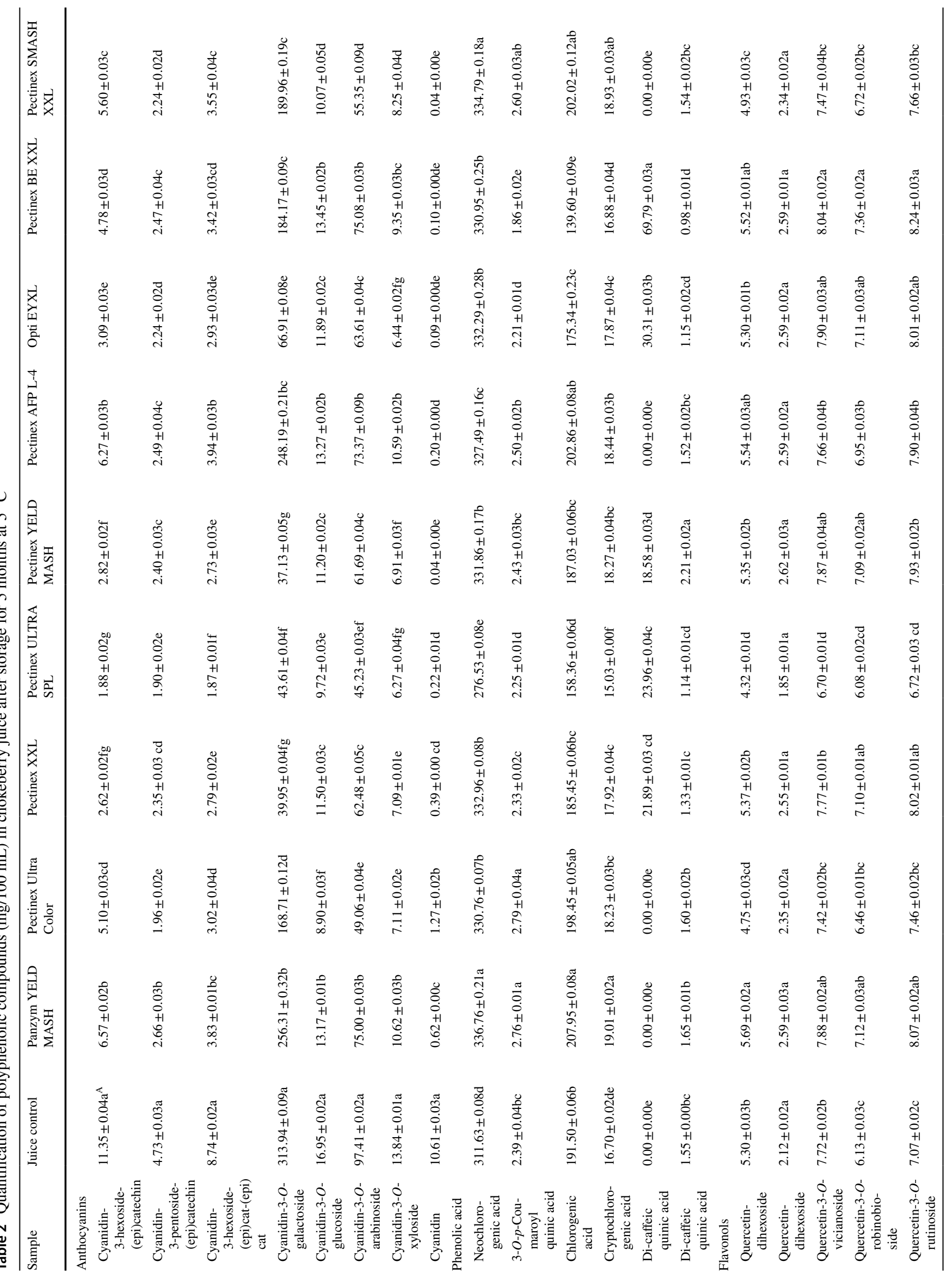




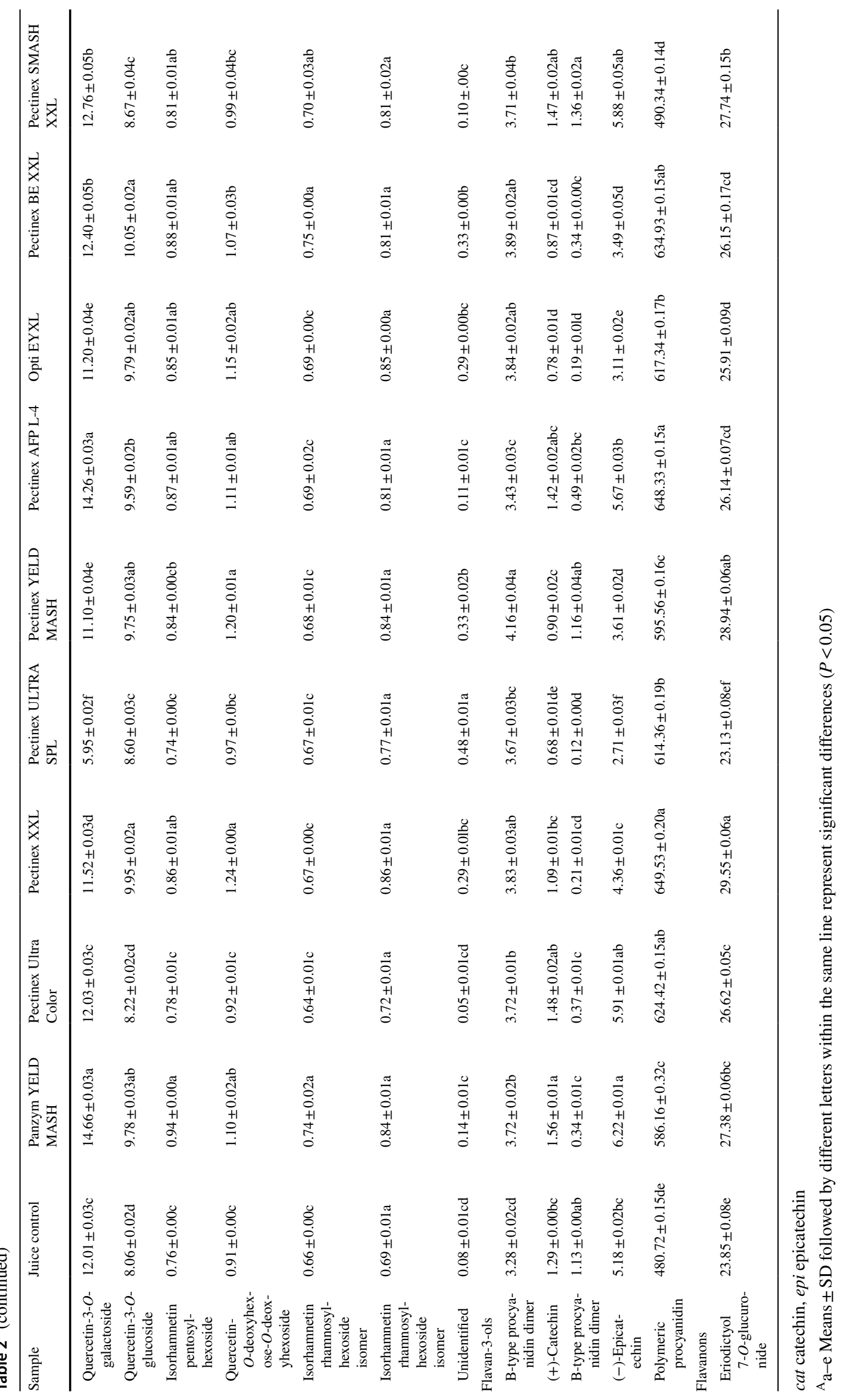


Fig. 1 The polyphenolic compounds $(\mathrm{mg} / 100 \mathrm{~mL})$ in chokeberry juice before $(0 \mathrm{~m})$ and after storage for 5 months at $5{ }^{\circ} \mathrm{C}(5 \mathrm{~m}) . F L$ flavonols, $F L V$ flavonons, $A N T$ anthocyanins, $P A$ phenolic acid, $F 3 O$ $M O$ flavan-3-ol monomers and oligomers, $P P$ polymeric procyanidins

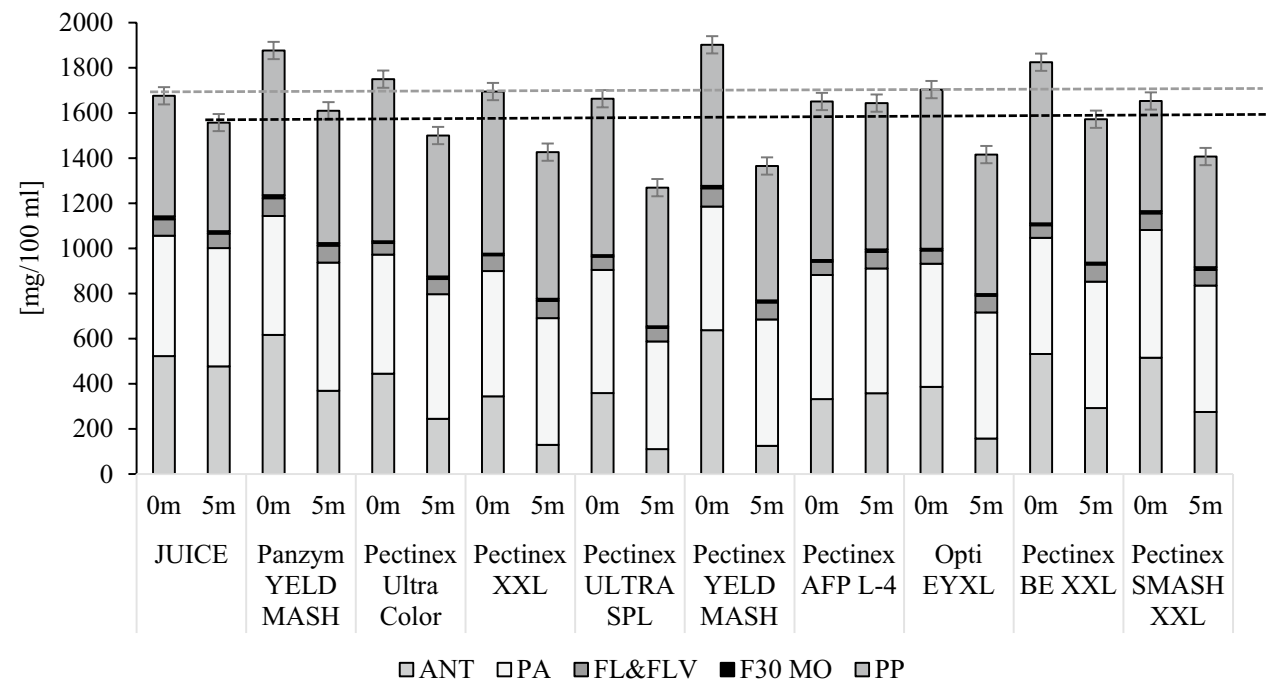

MASH (80\%), and the increase was found in juice with addition of Pectinex AFP L-4 (8\%). After storage, the value of aglycone cyanidin decreased by $94 \%$ and the value of cyanidin-3-O-galactoside was on average $10 \%$ higher than before storage. Buchert at al [23]. found that the most efficient enzyme to increase the value of anthocyanin extraction was Pectinex BE-3L, which increased the yield by $41 \%$ in blackcurrant juice. With the others, such as Pectinex Ultra SP-L and SMASH XXL, the increase was 13-16\%. Similar results of hydrolysis were described due to the Wightman and Wrolstad [11] and Buchert at al [23]. Probably new components such as aglycones were liberated by enzymatic hydrolysis from anthocyanidin glycosides. The production of unstable cyanidin aglycone takes place by the high presence of glycosidase activity.

The next group of identified polyphenolic compounds was hydroxycinnamic acids, which accounted for $31 \%$ of all identified compounds. The use of pectinolytic enzymes did not have a significant effect $(P<0.05)$ on the concentration of phenolic acids. The control sample before storage contained $533.40 \mathrm{mg} / 100 \mathrm{~mL}$ of phenolic compounds, which was $1.6 \%$ lower than samples with addition of enzymes. Neochlorogenic and chlorogenic acids were the major compounds belonging to phenolic acids in juice and accounted on average for 59 and $33 \%$ of all identified compounds. Similar results were described by Oszmiański and Lachowicz [17], Lachowicz et al. [12] and Ochmian et al. [24]. The content of hydroxycinnamic acids in control juice after storage was $1.8 \%$ lower than before storage. After 5 months of storage the largest decrease was identified in juice samples with addition of Pectinex ULTRA SPL (13\%).

The next examined group of polyphenolic compounds was total flavonols and flavonones, which accounted for $4 \%$ of all identified compounds. The use of pectinolytic enzymes did not have a significant effect $(P<0.05)$ on the content of flavonols and flavonones. The concentration of flavonols and flavonones was $73.14 \mathrm{mg} / 100 \mathrm{~mL}$ and was $11 \%$ higher than the content in samples with addition of enzymes. The content of flavonols and flavonones ranged from $80.53 \mathrm{mg} / 100 \mathrm{~mL}$ for juice with Pectinex ULTRA SPL to $50.99 \mathrm{mg} / 100 \mathrm{~mL}$ for juice with Pectinex Color. After 5 months' storage at $5{ }^{\circ} \mathrm{C}$, the concentration of flavonols and flavonones in control juice was $12 \%$ lower than before storage. The content of flavonols and flavonones after storage ranged from 76.27 to $59.80 \mathrm{mg} / 100 \mathrm{~mL}$ for juice with Pectinex XXL and Pectinex ULTRA SPL. The content of flavonols and flavonones in chokeberry juice with addition of enzymes was on average $16 \%$ lower than the value of these compounds in chokeberry juice after clarification with clarification agents [12]. The last group of polyphenolic compounds was flavan-3-ols, present in the form of monomers, oligomers and polymeric procyanidins, which accounted for $39 \%$ of all compounds. The content of flavan3-ols (monomeric and oligomeric) in control samples was $12.97 \mathrm{mg} / 100 \mathrm{~mL}$ and was $27 \%$ higher than the average content in juice with addition of enzymes. The highest content of flavan-3-ols was found in the juices with addition of Panzym YELD MASH (13.21 mg/100 mL) and the lowest was found in the samples with addition of Pectinex ULTRA SPL $(7.06 \mathrm{mg} / 100 \mathrm{~mL})$. After storage, the content of flavan3 -ols in control juice was $16 \%$ lower than before storage. The largest decrease of the content of flavan-3-ols was recorded in juice with addition of Pectinex YELD MASH (11\%), and the largest increase was found in juice with Pectinex AFP L-4 (36\%) and Pectinex Ultra Color (41\%).

The polymeric procyanidins are particularly important for the tart taste of juices and participate in the development of turbidity and precipitation. Procyanidin polymers exhibit high affinity for proteins, causing them to denature and cause a feeling of dryness in the oral cavity. This effect 
is noticeable when consuming fruit and chokeberry juice. These compounds accounted for $38 \%$ of all identified compounds. Used pectinolytic enzymes had a significant effect $(P<0.05)$ on the concentration of polymeric procyanidins. The content of polymeric procyanidins in control juice before storage was $534.37 \mathrm{mg} / 100 \mathrm{~mL}$ and was $10 \%$ lower than in juice samples with addition of enzymes. After 5 months at $5{ }^{\circ} \mathrm{C}$, the content of polymeric procyanidins in control samples was $6 \%$ lower than before storage. The largest decrease of polymeric procyanidins was in juice with addition of Pectinex Ultra Color (13\%), and the lowest was found in chokeberry juice with addition of Pectinex AFP L-4 (8\%). The degree of polymerisation of procyanidins, i.e. the number of flavan-3-ol units of catechin-linked monomers, modulates the physicochemical properties of procyanidins. According to literature data, the degree of polymerization of samples without and with enzymes was 21 and $27 \%$ higher in relation to the degree of polymerization of chokeberry fruit (26) analysed by Oszmiański and Wojdyło [19]. After storage, the degree of polymerisation was $9 \%$ lower than before storage, which means that products after storage are slightly less tart.

According to Bagger-Jørgensen and Meyer [22], the application of Pectinex Ultra SP-L leads to a higher content of flavan-3-ols (monomers, oligomers and polymeric procyanidin) than anthocyanins. They observed the opposite effect in a control sample. The flavan-3-ols and polymeric procyanidin can participate in the condensation reactions of anthocyanins in a mechanism of polymerization by direct anthocyanin-tannin reactions and can lead to degradation of anthocyanins in red juices. According to Lachowicz et al. [12], the flavan-3-ols and polymeric procyanidins in chokeberry juice clarified by polysaccharide clarification agents were on average $78 \%$ higher and $77 \%$ lower, respectively, than in a control sample and
$83 \%$ higher and $84 \%$ lower, respectively, than in juice with enzymes.

\section{Impact of pectinolytic enzymes on antioxidant capacity}

The results of the ABTS and FRAP assays are shown in Fig. 2. The addition of different pectinolytic enzymes to juice significantly $(P<0.05)$ affected the level of the antioxidative capacity (ABTS and FRAP assay). The antioxidant capacities measured by ABTS and FRAP tests in chokeberry juice (control sample) before storage were 11.58 and $6.64 \mathrm{mmol} \mathrm{TE} / 100 \mathrm{~mL}$ and were $12 \%$ lower than the antioxidant capacity in chokeberry juice with addition of pectinolytic enzymes. The antioxidant capacity ranged from 15.46 to $9.36 \mathrm{mmol} \mathrm{TE} / 100 \mathrm{~mL}$ (ABTS assay) and from 8.64 to $4.94 \mathrm{mmol}$ TE/100 mL (FRAP assay) for the chokeberry juice with addition of the enzymes Pectinex AFP L-4 and Pectinex SMASH XXL, respectively. The antioxidant capacity analysed by ABTS and FRAP assays in the control sample after 5 months at $5{ }^{\circ} \mathrm{C}$ was 30 and $19 \%$ lower than the antioxidant capacity in samples before storage. Additionally, average antioxidant capacity measured by ABTS and FRAP assays in chokeberry juice with addition of pectinolytic enzymes after storage was 28 and $17 \%$ higher than in the control sample. The largest decrease of antioxidant capacity was found in the samples with addition of Pectinex SMASH XXL: $48 \%$ (ABTS assay) and 38\% (FRAP assay). The smallest decrease of antioxidant capacity was recorded in the juice with addition of Panzym YELD MASH and Opti EYXL ( 3 and $7 \%$ for ABTS and 8 and $3 \%$ for FRAP).

According to Lachowicz et al. [12], the antioxidant capacity in chokeberry juice clarified by polysaccharide-based clarification agents were 3.4 and 2.6 times lower than the antioxidant capacity (ABTS and FRAP assay) in juice with
Fig. 2 The antioxidant capacity analysed by ABTS and FRAP assay (mmol TE/100 $\mathrm{mL}$ ) in chokeberry juice before $(0 \mathrm{~m})$ and after storage for 5 months at $5{ }^{\circ} \mathrm{C}(5 \mathrm{~m})$

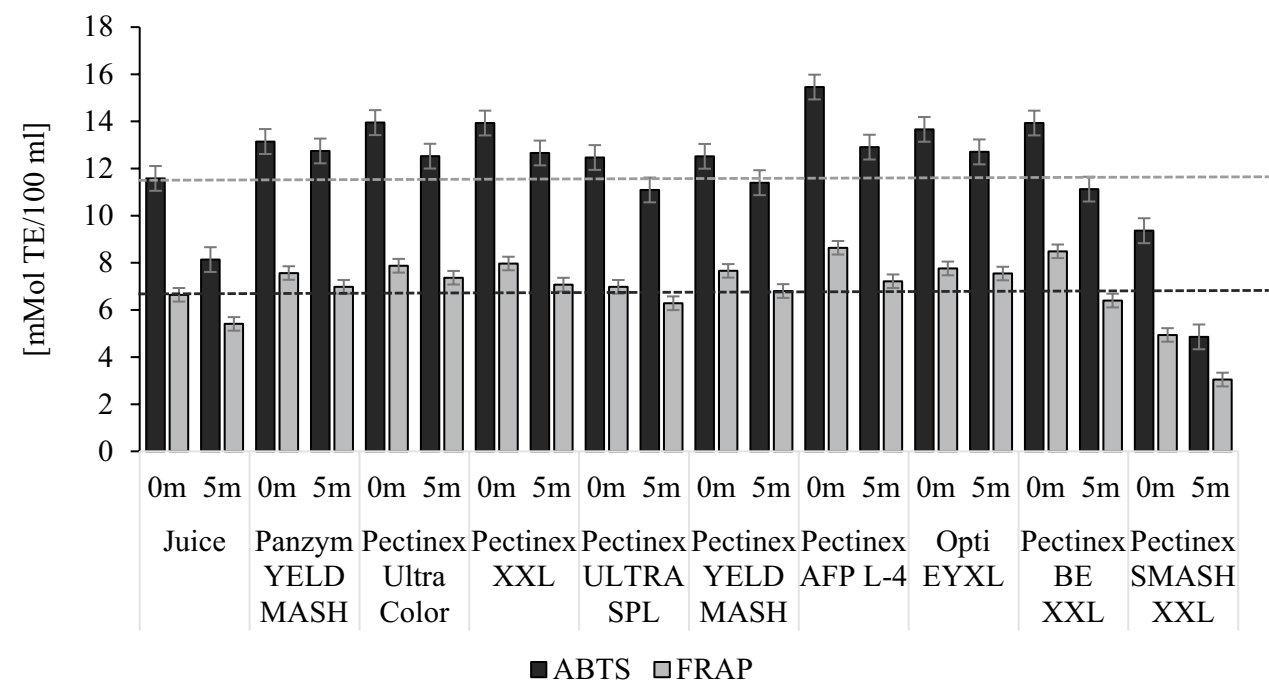


addition of pectinolytic enzymes. The result of antioxidant capacity (ABTS test) obtained by Oszmiański and Wojdyło [19] was 3.4 times lower than in juice with addition of enzymes. Kulling and Rawel [20] noted that the antioxidant potency of chokeberry juice analysed by ABTS assay was 6.5-7.0 mmol TE/100 mL, and was 1.7 and 1.9 times lower than the antioxidant capacity in chokeberry juice without and with addition of enzymes, respectively. Furthermore, the used pectinolytic enzymes showed less decrease of antioxidant potential, compared to clarifying agents based on bentonite, and proteins and polysaccharides of chokeberry juice [12].These pectinolytic enzymes can be used as an alternative in the process of clarification of chokeberry juice.

\section{Impact of pectinolytic enzymes on sugar content}

The results for the sugars fructose, sorbitol and glucose in the control sample and with enzymes before and after storage are presented in Fig. 3.

The addition of different pectinolytic enzymes to chokeberry juice significantly $(P<0.05)$ affected the content of sugar. The content of sugar in chokeberry juice without enzymes before storage was $19.63 \mathrm{~g} / 100 \mathrm{~mL}$ and was $13 \%$ higher than in juices with enzymes. This content of sugar was confirmed by Ochmian et al. [24]. The content of sugar ranged from 19.25 for juice with Pectinex BE XXL to $15.82 \mathrm{~g} / 100 \mathrm{~mL}$ for juice with Pectinex XXL. The content of sugar in the control sample after 5 months at $5{ }^{\circ} \mathrm{C}$ was $10 \%$ lower than before storage. The smallest decrease of the content of sugar after storage was recorded in the sample with addition of the enzyme Pectinex AFP L-4 (1\%) and the largest decrease was found in the chokeberry juice with addition of the enzyme Pectinex BE XXL (16\%). Additionally, sorbitol was the dominant compound in chokeberry juice among the three analysed sugars and accounted on average for $55 \%$ of all sugars. The content of glucose and fructose accounted on average for 29 and $16 \%$ of all sugars, respectively. Those results were also confirmed by the research of other authors $[17,20]$. In freshly pressed chokeberry juice sorbitol $(8 \mathrm{~g} / 100 \mathrm{~mL})$, glucose $(4.1 \mathrm{~g} / 100 \mathrm{~mL})$ and fructose $(3.8 \mathrm{~g} / 100 \mathrm{~mL})$ were identified [20]. According to Oszmiański and Lachowicz [17], sorbitol was the dominant sugar in chokeberry juice and accounted for $48 \%$ of all analysed sugar, while glucose and fructose accounted for 30 and $22 \%$ of all sugar in chokeberry juice.

\section{Impact of pectinolytic enzymes on viscosity, turbidity, and precipitate}

The main physical parameters of obtained juices without and with addition of pectinolytic enzymes before and after storage are analysed in this study and presented in Table 3. The quality parameters measured in the resulting juices were turbidity and precipitation, both depending on different sizes of particles. Particles with diameters in the range of 1-100 $\mu \mathrm{m}$ show low sedimentation, and when the diameters are bigger than $1 \mathrm{~mm}$ sedimentation is higher [12]. The addition of different pectinolytic enzymes to juice significantly $(P<0.05)$ affected the value of turbidity. The level of turbidity in the control sample before storage was 575 NTU and was $99 \%$ higher than average values of turbidity in samples with addition of enzymes. The lowest values of turbidity were found in the chokeberry juice with addition of Pectinex AFP L-4, Pectinex XXL, Opti EYXL and Pectinex Ultra Color and were $0.29,0.34,0.36$ and $0.99 \mathrm{NTU}$, respectively. The highest value of turbidity was recorded in the juice sample with addition of Pectinex SMASH XXL and was 14.78 NTU. The storage time also significantly $(P<0.05)$ affected the decrease of the values of turbidity and precipitation. The value of turbidity in control juice after 5 months at $5{ }^{\circ} \mathrm{C}$ was $56 \%$ lower than before storage. The largest decreases of turbidity value in juices with enzymes were found in the samples with Pectinex SMASH XXL (96\%), Pectinex YELD MASH (93\%) and Pectinex BE XXL (92\%). The lowest turbidity was found in the products with Pectinex AFP L-4 (0NTU) and Opti EYXL (0.14NTU).
Fig. 3 The content of sugars $(\mathrm{g} / 100 \mathrm{~mL})$ in chokeberry juice before $(0 \mathrm{~m})$ and after storage for 5 months at $5{ }^{\circ} \mathrm{C}(5 \mathrm{~m})$. Fructose (black colour), Sorbitol (light grey colour), Glucose (gray)

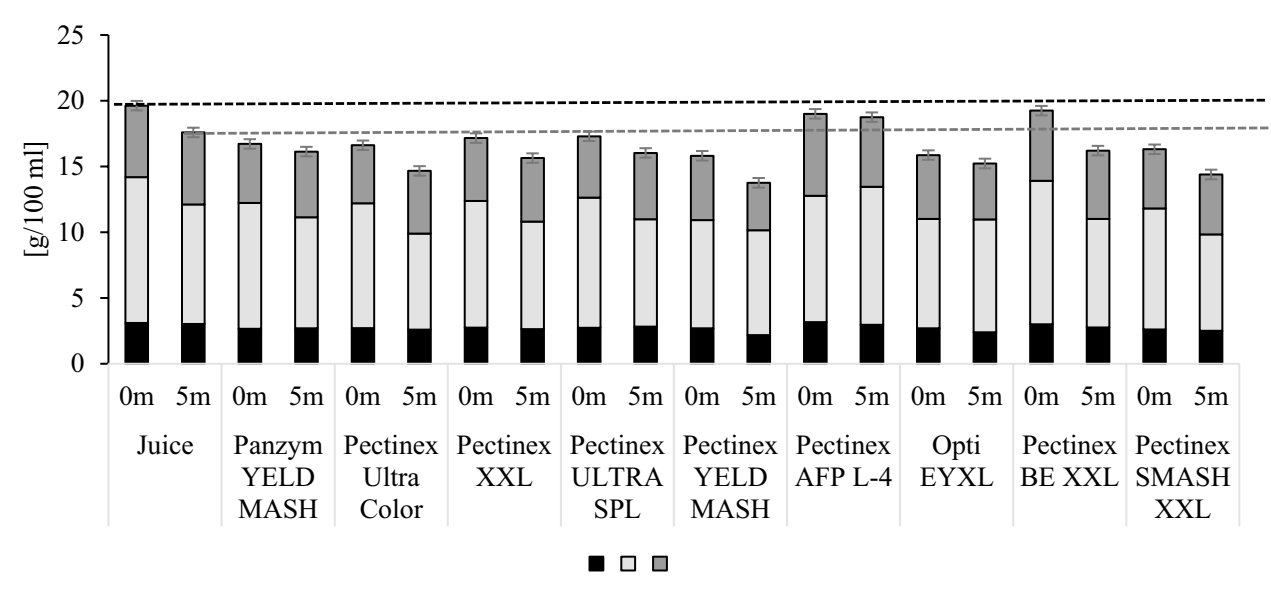


Table 3 Turbidity, viscosity, and precipitate in chokeberry juice before and after storage for 5 months at $5{ }^{\circ} \mathrm{C}$

\begin{tabular}{|c|c|c|c|c|c|}
\hline \multirow[t]{2}{*}{ Samples } & \multicolumn{2}{|l|}{ Turbidity (NTU) } & \multicolumn{2}{|c|}{ Viscosity (mPa s) } & \multirow{2}{*}{$\begin{array}{l}\text { Precipitate (\%) } \\
5 \mathrm{~m} / 5^{\circ} \mathrm{C}\end{array}$} \\
\hline & $0 \mathrm{~m}$ & $5 \mathrm{~m} / 5^{\circ} \mathrm{C}$ & $0 \mathrm{~m}$ & $5 \mathrm{~m} / 5^{\circ} \mathrm{C}$ & \\
\hline Juice control & $575.00 \pm 0.07 \mathrm{~h}^{\mathrm{A}}$ & $251.00 \pm 0.04 \mathrm{~h}$ & $8.10 \pm 0.02 \mathrm{c}$ & $3.54 \pm 0.02 \mathrm{gh}$ & $2.81 \mathrm{e}$ \\
\hline Panzym YELD MASH & $8.37 \pm 0.02 f$ & $0.97 \pm 0.03 \mathrm{~g}$ & $5.10 \pm 0.02 b$ & $2.55 \pm 0.03 f$ & $1.47 \mathrm{a}$ \\
\hline Pectinex Ultra Color & $0.99 \pm 0.02 \mathrm{c}$ & $0.65 \pm 0.04 \mathrm{e}$ & $4.86 \pm 0.03 a$ & $3.19 \pm 0.04 \mathrm{~g}$ & $2.91 \mathrm{ef}$ \\
\hline Pectinex XXL & $0.34 \pm 0.03 b$ & $0.28 \pm 0.02 \mathrm{~cd}$ & $4.92 \pm 0.04 a$ & $4.05 \pm 0.02 \mathrm{~h}$ & $2.30 \mathrm{~cd}$ \\
\hline Pectinex ULTRA SPL & $1.10 \pm 0.02 \mathrm{~cd}$ & $0.44 \pm 0.01 \mathrm{e}$ & $4.86 \pm 0.03 a$ & $1.94 \pm 0.01 \mathrm{~cd}$ & $1.55 \mathrm{ab}$ \\
\hline Pectinex YELD MASH & $3.62 \pm 0.04 \mathrm{~d}$ & $0.26 \pm 0.03 c$ & $4.62 \pm 0.02 \mathrm{a}$ & $2.31 \pm 0.02 \mathrm{e}$ & $2.24 \mathrm{c}$ \\
\hline Pectinex AFP L-4 & $0.29 \pm 0.03 a$ & $0.00 \pm 0.00 \mathrm{a}$ & $4.74 \pm 0.04 a$ & $1.63 \pm 0.03 b$ & $2.06 \mathrm{bc}$ \\
\hline Opti EYXL & $0.36 \pm 0.03 b$ & $0.14 \pm 0.02 \mathrm{ab}$ & $4.68 \pm 0.02 \mathrm{a}$ & $1.82 \pm 0.02 \mathrm{c}$ & $2.87 \mathrm{e}$ \\
\hline Pectinex BE XXL & $3.98 \pm 0.04 \mathrm{e}$ & $0.33 \pm 0.03 \mathrm{~d}$ & $4.56 \pm 0.04 a$ & $1.38 \pm 0.02 \mathrm{ab}$ & $2.54 \mathrm{~d}$ \\
\hline Pectinex SMASH XXL & $14.78 \pm 0.05 \mathrm{~g}$ & $0.53 \pm 0.03 f$ & $4.98 \pm 0.03 a$ & $1.18 \pm 0.03 \mathrm{a}$ & $1.70 \mathrm{~b}$ \\
\hline
\end{tabular}

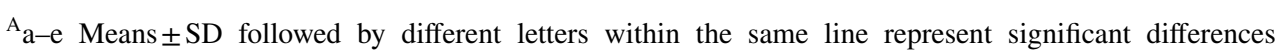
$(P<0.05)$
The value of precipitation after 5 months' storage of chokeberry juice without enzymes was $2.81 \%$ and was $22 \%$ higher than the average value of precipitation in juice with addition of enzymes. The precipitation in chokeberry juice with enzymes ranged from 2.91 for Pectinex Ultra Color to $1.47 \%$ for Panzym YELD MASH and Pectinex ULTRA SPL.

The next quality discriminant measured in the resulting samples was viscosity. The addition of pectinolytic enzymes to the chokeberry juice did not significantly $(P<0.05)$ affect the value of viscosity. The viscosity in the juice sample without enzymes before storage was $8.10 \mathrm{mPa}$ s and was $40 \%$ higher than average values of viscosity of juice with addition of pectinolytic enzymes. Furthermore, the storage time significantly $(P<0.05)$ affected the viscosity of chokeberry juices. The value of viscosity in the control sample after 5 months was $56 \%$ lower than before storage. The largest decrease of viscosity was in chokeberry juice with addition of the enzymes Pectinex SMASH XXL (76\%), Pectinex BE XXL (70\%), Opti EYXL (61\%), Pectinex AFP L-4 (66\%), and Pectinex ULTRA SPL (60\%), and the smallest decrease was in the sample with Pectinex XXL (18\%).

In addition, Kalisz et al. [25] explain that during the storage of chokeberry juice a polyphenol polymerization reaction may occur, affecting the formation of multi-particulates, which have lower solubility. These compounds may affect the formation of sediments and turbidity. In addition, in beverages and juices rich in polyphenolic compounds, deposits and turbidity are observed during storage [26]. The use of enzyme preparations caused the high solubility and lack of formation of such molecules. The pectinolytic enzymes used showed lower values of turbidity and precipitation, compared to clarifying agents based on bentonite and proteins. These pectinolytic enzymes can be used as an alternative in the process of clarifying chokeberry juice, besides polysaccharides [12].
Enzymatic treatment is carried out to break down multiparticulated complex carbohydrates into compounds with lower molecular weights. Examples of such polysaccharides are pectins, which hinder clarification and filtration by increasing the viscosity of the juice and clogging of filtres. Pectin hydrolysis, which leads to the formation of poly-dgalacturonic acid fragments, causes a decrease of viscosity, turbidity in juice and an increase of efficiency of filtration process, which facilitates the subsequent juice filtration process [27].

\section{Impact of pectinolytic enzymes on colour}

The colour parameter affects the first contact of the person with a product, and their decision to choose the product [28, 29]. The colour parameters $L^{*}, a^{*}, b^{*}, \Delta E, \Delta C$ and $H^{0}$ in the juice without and with enzymes before and after 5 months of storage are presented in Table 4.

In the juice without enzymes, the average $L^{*}, a^{*}$, and $b^{*}$ parameters before storage were 28.33, 59.02 and 47.26. The average darkest juices were samples with addition of Pectinex XXL $\left(L^{*}=27.81\right)$, and the lightest was sample with addition of Opti EYXL $\left(L^{*}=29.15\right)$. The colour parameter $L^{*}$ in control juice after 5 months' storage at $5{ }^{\circ} \mathrm{C}$ was $14 \%$ lower than in the control sample before storage. The samples after storage were $4 \%$ lighter than the control juice. The biggest brightening of parameter $L^{*}$ was found in chokeberry juice with Panzym YELD MASH and Pectinex Ultra Color around 3\%, and the smallest was found in juice with Pectinex SMASH XXL around $6 \%$.

The different enzymes added to juice did not significantly $(P<0.05)$ affect the final red colour. The red colour in control juice after 5 months' storage was $7 \%$ higher than in the control sample before storage. The addition of different pectinolytic enzymes to chokeberry juice did not significantly affect the parameter $a^{*}$, whereas 5 months' storage 
Table 4 Colour parameters in chokeberry juice before and after storage for 5 months at $5{ }^{\circ} \mathrm{C}$

\begin{tabular}{|c|c|c|c|c|c|c|c|}
\hline Time & Samples & $L^{*}$ & $a^{*}$ & $b^{*}$ & $\Delta E$ & $\Delta C$ & $H^{0}$ \\
\hline \multirow[t]{10}{*}{$0 \mathrm{~m}$} & Juice control & $28.33 \pm 0.04^{\mathrm{A}}$ & $59.02 \pm 0.02 \mathrm{a}$ & $47.26 \pm 0.03 \mathrm{a}$ & - & - & - \\
\hline & Panzym YELD MASH & $28.32 \pm 0.03 b$ & $59.02 \pm 0.03 \mathrm{a}$ & $47.37 \pm 0.03 a$ & $1.08 \mathrm{ab}$ & $0.72 b$ & $0.79 b$ \\
\hline & Pectinex Ultra Color & $28.38 \pm 0.02 b$ & $60.08 \pm 0.03 \mathrm{a}$ & $47.20 \pm 0.04 \mathrm{a}$ & $1.33 \mathrm{bc}$ & $0.35 \mathrm{ab}$ & $1.17 \mathrm{c}$ \\
\hline & Pectinex XXL & $27.81 \pm 0.03 \mathrm{a}$ & $59.47 \pm 0.04 a$ & $46.23 \pm 0.03 a$ & $1.67 \mathrm{c}$ & $1.51 \mathrm{c}$ & $0.18 \mathrm{a}$ \\
\hline & Pectinex ULTRA SPL & $29.02 \pm 0.02 b c$ & $60.31 \pm 0.02 \mathrm{a}$ & $48.17 \pm 0.02 \mathrm{a}$ & $1.02 \mathrm{ab}$ & $0.39 \mathrm{ab}$ & $0.84 b$ \\
\hline & Pectinex YELD MASH & $27.89 \pm 0.02 \mathrm{a}$ & $59.24 \pm 0.03 \mathrm{a}$ & $46.47 \pm 0.03 \mathrm{a}$ & $1.19 \mathrm{~b}$ & $0.50 \mathrm{ab}$ & $1.07 \mathrm{bc}$ \\
\hline & Pectinex AFP L-4 & $28.28 \pm 0.04 b$ & $60.08 \pm 0.03 \mathrm{a}$ & $46.84 \pm 0.04 \mathrm{a}$ & $2.05 \mathrm{~d}$ & $1.87 \mathrm{c}$ & $0.13 \mathrm{ab}$ \\
\hline & Opti EYXL & $29.15 \pm 0.03 \mathrm{c}$ & $60.56 \pm 0.04 \mathrm{a}$ & $48.44 \pm 0.02 \mathrm{a}$ & $0.88 \mathrm{a}$ & $0.27 \mathrm{a}$ & $0.82 b$ \\
\hline & Pectinex BE XXL & $28.14 \pm 0.02 \mathrm{ab}$ & $59.74 \pm 0.02 \mathrm{a}$ & $46.90 \pm 0.03 a$ & $1.38 \mathrm{bc}$ & $0.26 \mathrm{a}$ & $1.28 \mathrm{~cd}$ \\
\hline & Pectinex SMASH XXL & $27.85 \pm 0.03 a$ & $59.61 \pm 0.04 a$ & $46.21 \pm 0.03 a$ & $9.75 \mathrm{e}$ & $8.00 \mathrm{~d}$ & $3.05 \mathrm{e}$ \\
\hline \multirow[t]{10}{*}{$5 \mathrm{~m} / 5^{\circ} \mathrm{C}$} & Juice control & $32.98 \pm 0.01 \mathrm{~cd}$ & $63.21 \pm 0.03 a$ & $54.84 \pm 0.02 \mathrm{ab}$ & $10.32 \mathrm{f}$ & $7.37 \mathrm{e}$ & $4.66 \mathrm{e}$ \\
\hline & Panzym YELD MASH & $33.82 \pm 0.03 \mathrm{~d}$ & $61.57 \pm 0.03 a$ & $55.70 \pm 0.02 \mathrm{a}$ & $3.83 \mathrm{bc}$ & $3.17 \mathrm{bc}$ & $1.13 \mathrm{ab}$ \\
\hline & Pectinex Ultra Color & $33.84 \pm 0.04 d$ & $61.6 \pm 0.03 \mathrm{a}$ & $55.70 \pm 0.02 \mathrm{a}$ & $3.08 \mathrm{~b}$ & $2.18 b$ & $1.25 \mathrm{~b}$ \\
\hline & Pectinex XXL & $30.14 \pm 0.03 \mathrm{ab}$ & $60.76 \pm 0.04 a$ & $50.25 \pm 0.02 b c$ & $4.76 \mathrm{c}$ & $3.27 \mathrm{bc}$ & $1.97 \mathrm{bc}$ \\
\hline & Pectinex ULTRA SPL & $30.09 \pm 0.02 \mathrm{ab}$ & $59.92 \pm 0.03 a$ & $49.72 \pm 0.02 c$ & $5.71 \mathrm{~d}$ & $3.93 \mathrm{c}$ & $2.36 \mathrm{c}$ \\
\hline & Pectinex YELD MASH & $31.16 \pm 0.02 b$ & $60.29 \pm 0.02 \mathrm{a}$ & $50.97 \pm 0.03 b c$ & $7.64 \mathrm{e}$ & $6.04 \mathrm{~d}$ & $2.74 \mathrm{~cd}$ \\
\hline & Pectinex AFP L-4 & $31.73 \pm 0.02 b c$ & $60.54 \pm 0.02 \mathrm{a}$ & $51.69 \pm 0.03 b$ & $5.51 \mathrm{~d}$ & $3.81 \mathrm{c}$ & $2.19 b c$ \\
\hline & Opti EYXL & $32.12 \pm 0.02 \mathrm{c}$ & $61.91 \pm 0.04 \mathrm{a}$ & $53.34 \pm 0.01 \mathrm{ab}$ & $2.20 \mathrm{ab}$ & $1.42 \mathrm{ab}$ & $0.88 \mathrm{ab}$ \\
\hline & Pectinex BE XXL & $31.64 \pm 0.03 b c$ & $60.56 \pm 0.03 a$ & $51.49 \pm 0.03 b$ & $1.15 \mathrm{a}$ & $0.88 \mathrm{a}$ & $0.39 \mathrm{a}$ \\
\hline & Pectinex SMASH XXL & $29.75 \pm 0.01 \mathrm{a}$ & $59.57 \pm 0.02 \mathrm{a}$ & $48.95 \pm 0.03 \mathrm{~cd}$ & $12.47 \mathrm{~g}$ & $9.49 \mathrm{f}$ & $4.87 \mathrm{ef}$ \\
\hline
\end{tabular}

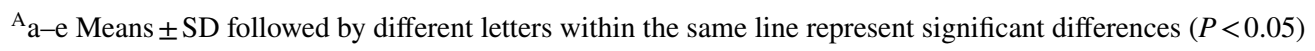

significantly affected the attractive colour, the juices being redder, which was in agreement with other authors [12, 29, 30]. The different enzymes added to juice did not significantly $(P<0.05)$ affect the yellow colour. The yellow colour, parameter $\mathrm{b}^{*}$ in control juice after 5 months' storage at $5{ }^{\circ} \mathrm{C}$, was $14 \%$ higher than in the control sample before storage. The highest value of yellow colour was found in juice with Panzym XEDL MASH and Pectinex Ultra Color ( $\left.\mathrm{b}^{*}=55.70\right)$, and the lowest was found in juice with Pectinex SMASH XXL $\left(b^{*}=48.95\right)$.

The parameter $\Delta E$ was also identified in the obtained juices. $\Delta \mathrm{E}$ expresses the human eye's ability to discriminate between the colours of products. It is accepted that a person can only distinguish the hues between two samples when parameter $\Delta E \geq 5$ units [31]. Compared to the juice with enzymes before storage $\Delta E$ ranged from 9.75 in the chokeberry juice with addition of Pectinex SMASH XXL to 0.88 in the chokeberry juice with addition of Opti EYXL. After 5 months' storage at $5{ }^{\circ} \mathrm{C}$, the amount of the parameter $\Delta \mathrm{E}$ of juice ranged from 12.47 to 1.15 for juice for Pectinex SMASH XXL and BE XXL, respectively. Wirth et al. [32] reported that juices with different addition agents or juices contained different types of hue and have an effect on the good quality of products. Changes in chemical and physical composition and bioactive compounds in juices with different pectinolytic enzymes affect their colour. The differences probably arise from addition of different pectinolytic enzymes.

\section{Principal component analysis}

The results indicating differences between physical and bioactive antioxidant parameters were emphasised during PCA. Then, two main PCs for the measured chokeberry juices without and with enzymes accounted for $55.00 \%$ of total variability, $\mathrm{PC} 1$ for $33.00 \%$ and $\mathrm{PC} 2$ for $22.06 \%$, as shown in Fig. 4. The results obtained from PCA presented of four clusters:

1. Samples without enzymes and with Panzym YELD MASH with a higher concentration of anthocyanins, flavan-3-ols, flavonols, flavonones and phenolics, and high turbidity and viscosity.

2. Samples with Pectinex: YELD MASH, SMASH XXL, XXL with a higher concentration of phenolic acids and high colour parameters: $\Delta E, \Delta C$ and $H^{0}$.

3. Samples with Pectinex: AFP L-4 and BE XXL with high content of glucose, fructose, sorbitol, sugar and precipitate.

4. Samples with Pecrinex: Ultra Color, ULTRA SPL, Opti EYXL with a higher content of polymeric procyanidin and high degree of polymerisation and positive cor- 
Fig. 4 PCA analysis presenting the relationship among phytochemical parameters and antioxidant capacity of chokeberry juice without and with pectinolytic enzymes. $F L$ flavonols, FLW flavonons, ANT anthocyanins, $P A$ phenolic acid, F3O MO flavan-3-ol monomers and oligomers, $P C$ polyphenolic compounds, $P P$ polymeric procyanidins, $D P$ degree of procyanidins polymerization

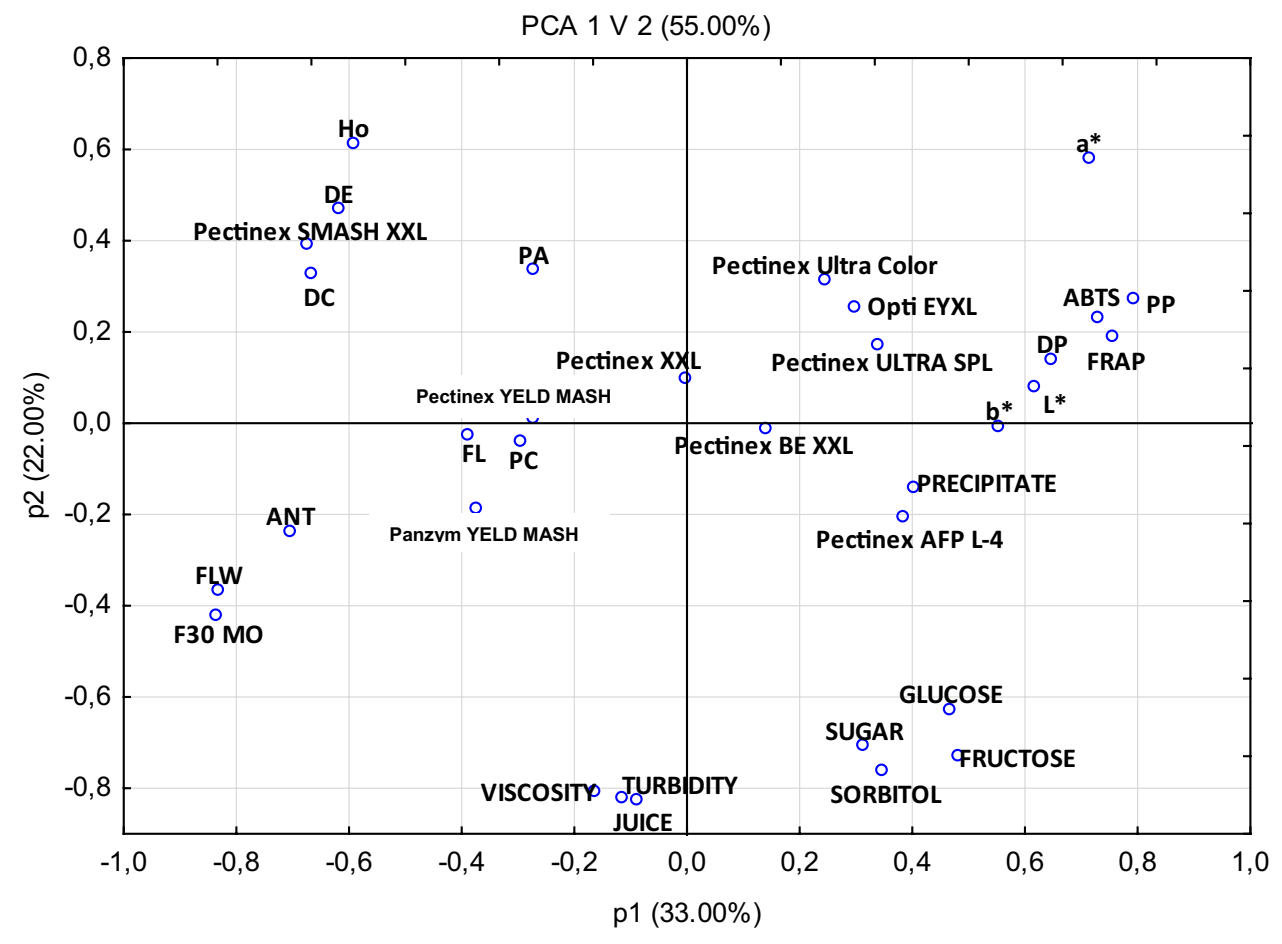

relation with ABTS and FRAP assay, and high colour parameters: $L^{*}, a^{*}, b^{*}$.

\section{Cluster analysis}

The use of hierarchical cluster analysis allowed definition of four areas of relationships between enzymes added to chokeberry juice and the level of chemical and physical parameters and bioactive compounds in the chokeberry juice (Fig. 5). In the first cluster, grouped around the sample without enzymes, there were the factors exhibiting a positive effect of Pectinex SMASH XXL on the level of all parameters in chokeberry juice. This area had a mean $10 \%$ increase in all parameters. The next area, in which the average increase in the content of all parameters was $20 \%$, was determined by Panzym YELD MASH and Pectinex YELD
Fig. 5 The influence of pectinolytic enzymes on analysed parameters in chokeberry juice

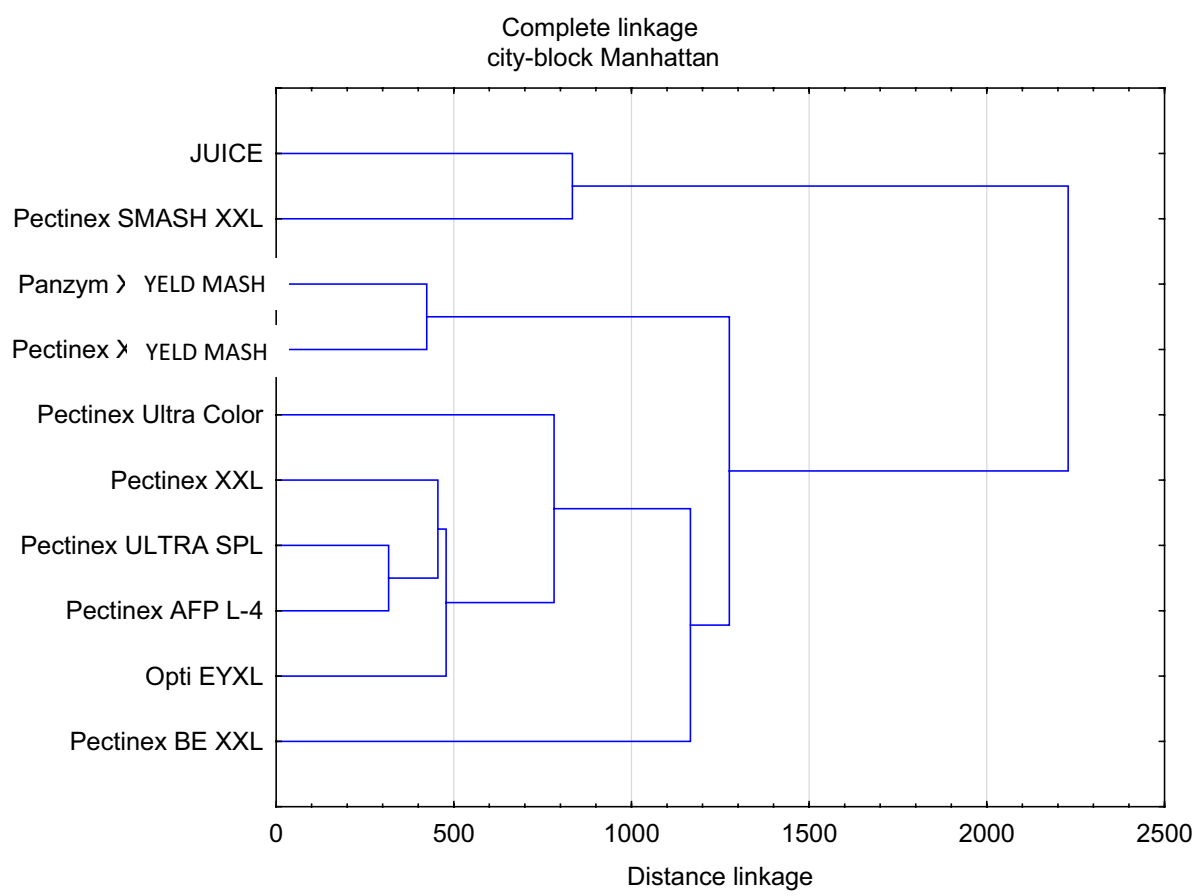


MASH. The another cluster in which the average increase in the content of all parameters in chokeberry juice was 50\% were determined by Pectinex XXL, ULTRA SPL, AFP 1-4 and Opti EYXL. The last area comprised Pectinex BE XXL, which had a distinct adverse effect on the level of all parameters, reducing their amount on average by $10 \%$.

\section{Conclusion}

In summary, pectinolytic enzymes such as Panzym YELD MASH, Pectinex YELD MASH and Opti EYXL after $24 \mathrm{~h}$ provided high content of polyphenolic compounds, primarily anthocyanins, polymeric procyanidins and phenolic acids, high antioxidant potency and low values of turbidity and precipitation. The colour of juices with these enzymes was red and attractive and without browning. Therefore, Panzym YELD MASH, Pectinex YELD MASH and Opti EYXL are strongly recommended for the process of clarification of chokeberry juices and probably for the pre-treatment of chokeberry pulp. These pectinolytic enzymes after 5 months' storage at $5{ }^{\circ} \mathrm{C}$ also influenced the stability and protection of chemical, physical and bioactive potency in the chokeberry juice.

Acknowledgements A part of this work was financially supported by the National Research and Development Centre granted on the basis of decision PBS3/B8/21/2015. The publication was supported by Wroclaw Centre of Biotechnology, under the programme The Leading National Research Centre (KNOW) for the years 2014-2018.

\section{Compliance with ethical standards}

Compliance with ethics requirements All authors declare that this article does not contain any studies with human or animal subjects.

Conflict of interest The authors declare no conflict of interest.

Open Access This article is distributed under the terms of the Creative Commons Attribution 4.0 International License (http://creativeco mmons.org/licenses/by/4.0/), which permits unrestricted use, distribution, and reproduction in any medium, provided you give appropriate credit to the original author(s) and the source, provide a link to the Creative Commons license, and indicate if changes were made.

\section{References}

1. Gerard KA, Roberts JS (2004) LWT Food Sci Technol 37(5):551-557
2. Seeram NP (2008) J Agric Food Chem 56(3):630-635

3. Ribeiro DS, Henrique S, Oliveira LS, Macedo GA, Fleuri LF (2010) Inter J Food Sci Technol 45(4):635-641

4. Smeriglio A, Barreca D, Bellocco E, Trombetta D (2016) Phytother Res 30(8):1265-1286

5. Brownmiller C, Howard LR, Prior RL (2008) J Food Sci 73(5)

6. He J, Giusti MM (2010) Annu Rev Food Sci Technol 1:163-187

7. Weber F, Larsen LR (2017) Food Res Inter 100:354-365

8. Patras A, Brunton NP, O'Donnell C, Tiwari BK (2010) Trends Food Sci Technol 21(1):3-11

9. Bhat MK (2000) Biotechnol Adv 18(5):355-383

10. Howard LR, Prior RL, Liyanage R, Lay JO (2012) J Agric Food Chem 60(27):6678-6693

11. Wightman JD, Wrolstad RE (1996) J Food Sci 61(3):544-548

12. Lachowicz S, Oszmiański J, Kalisz S (2018) LWT Food Sci Technol 92:347-360

13. Lachowicz S, Oszmiański J, Pluta S (2017) Food Chem 235:234-243

14. Lachowicz S, Wojdyło A, Chmielewska J, Oszmiański J (2017) Eur Food Res Technol 1-11

15. Re R, Pellegrini N, Proteggente A, Pannala A, Yang M, RiceEvans C (1999) Free Radic Biol Med 26(9):1231-1237

16. Benzie IF, Strain JJ (1996) Anal Biochem 239(1):70-76

17. Oszmiański J, Lachowicz S (2016) Molecules 21(8):1098

18. Cebulak T, Oszmiański J, Kapusta I, Lachowicz S (2017) Molecules 22(7):1161

19. Oszmiański J, Wojdylo A (2005) Eur Food Res Technol 221:809-813

20. Kulling SE, Rawel HM (2008) Plant Med 74(13):1625-1634

21. Landbo AK, Meyer AS (2004) Innov Food Sci Emerg Technol 5(4):503-513

22. Bagger-Jørgensen R, Meyer AS (2004) Eur Food Res Technol 219(6):620-629

23. Buchert J, Koponen JM, Suutarinen M, Mustranta A, Lille M, Törrönen R, Poutanen K (2005) J Sci Food Agric 85(15):2548-2556

24. Grajkowski OchmianD, Smolik J M (2012) Notulae Botanic Hortic Agrobot Cluj Napoca 40(1):253

25. Kalisz B, Kalisz S, Oszmiański J (2001) Food Sci Technol Qual 8(2):94-103

26. Rødtjer A, Skibsted LH, Andersen ML (2010) Food Chem 123:1035-1039

27. Heffels P, Bührle F, Schieber A, Weber F (2017) Eur Food Res Technol 243(1):59-68

28. Mena P, García-Viguera C, Navarro-Rico J, Moreno DA, Bartual J, Saura D, Martí N (2011) J Sci Food Agric 91(10):1893-1906

29. Gallego MG, García-Carpintero EG, Sánchez-Palomo E, Viñas MG, Hermosín-Gutiérrez I (2013) Food Res Inter 51(2):554-563

30. Oszmiański J, Wojdyło A, Lachowicz S (2016) LWT Food Sci Technol 67:214-222

31. Pérez-Magariño S, González-Sanjosé ML (2003) Food Chem 81(2):301-306

32. Wirth J, Morel-Salmi C, Souquet JM, Dieval JB, Aagaard O, Vidal S, Fulcrand H, Cheynier V (2010) Food Chem 123(1):107-116 